Research Article

\title{
Pottery Sand as Fine Aggregate for Preparing Alkali-Activated Slag Mortar
}

\author{
Zhenzhen Jiao $\mathbb{D}^{1,2,3}$ Ying Wang, ${ }^{1,2,3}$ Wenzhong Zheng, ${ }^{1,2,3}$ and Wenxuan Huang ${ }^{1,2,3}$ \\ ${ }^{1}$ Key Lab of Structures Dynamic Behavior and Control of the Ministry of Education, Harbin Institute of Technology, \\ Harbin 150090, China \\ ${ }^{2}$ Key Lab of Smart Prevention and Mitigation of Civil Engineering Disasters of the Ministry of Industry and Information \\ Technology, Harbin Institute of Technology, Harbin 150090, China \\ ${ }^{3}$ School of Civil Engineering, Harbin Institute of Technology, Harbin 150090, China
}

Correspondence should be addressed to Zhenzhen Jiao; jiaozhenzhen@hit.edu.cn

Received 6 March 2018; Accepted 6 May 2018; Published 20 May 2018

Academic Editor: Antonio Caggiano

Copyright $(2018$ Zhenzhen Jiao et al. This is an open access article distributed under the Creative Commons Attribution License, which permits unrestricted use, distribution, and reproduction in any medium, provided the original work is properly cited.

Alkali-activated slag (AAS) mortars were prepared using pottery sand as a fine aggregate in a ratio of $1: 1.75$ using a blend of sodium silicate and $\mathrm{NaOH}$ as an alkaline activator at room temperature. The effects of sodium oxide content and silicate moduli on the setting time, fluidity, consistency, compressive strength, and drying shrinkage of different AAS mortars were determined. These results revealed that sodium oxide content and silicate modulus had little effect on the setting time and workability of the mortar; however, they did have a significant effect on their mechanical performance and drying shrinkage levels. All the AAS mortars exhibited faster setting times, better workability, and higher early and late compressive strength compared to traditional mortars. Optimum compressive strength was achieved at 93 and $123 \mathrm{MPa}$ after $1 \mathrm{~d}$ and $28 \mathrm{~d}$, respectively, using a silicate modulus of 1.2 and $\mathrm{Na}_{2} \mathrm{O}$ content of $8 \%$. The microstructures of mortars were characterized using scanning electron microscopy with energy dispersive spectrometric (SEM/EDS) and mercury intrusion porosimetry (MIP). These results reveal that AAS mortars containing pottery sand as a fine aggregate may represent a promising building material with improved properties for use in the construction industry.

\section{Introduction}

Blast furnace slag is a solid waste product from the steel making process that is produced by rapid cooling of molten slag at the furnace exit [1]. Therefore, its transformation into building materials that can be used by the construction industry represents an environmentally friendly and economically useful use for this waste material. Furthermore, blast furnace slag has often been used in the construction industry as an alternative mineral admix to cement for incorporation into concrete materials [2]. However, current processes only employ a small amount of the slag that is potentially available for construction applications, with its utility for building applications currently underexploited $[2,3]$. Blending slag with an alkaline activator has previously been shown to afford cementitious materials with excellent potential for construction applications [4-6]. This is because the alkali activation process affords slag-derived mortars with improved strength and decreased setting times when compared to more conventional mortars. Consequently, the use of AAS (alkali-activated slag) processes for the preparation of cementitious materials has gained in popularity, primarily due to lower $\mathrm{CO}_{2}$ emissions in its manufacturing process and the improved performance properties of the mortars that it produces [7]. Other significant advantages that AAS mortars have over Portland cement include better mechanical properties, superior frost resistance, lower porosity, and lower permeability to water. However, AAS mortars also have some disadvantages, including faster setting properties and higher levels of mass loss and drying shrinkage during their curing phases.

A range of protocols for the preparation of AAS mortars have been reported by a number of different research groups. Their studies have shown that the type of aggregate employed for the preparation of AAS mortar plays a significant role in determining its physical and hardening 
TABLE 1: Chemical composition (\%) of slag and pottery sand.

\begin{tabular}{lcccccccccc}
\hline & $\mathrm{SiO}_{2}$ & $\mathrm{Al}_{2} \mathrm{O}_{3}$ & $\mathrm{CaO}$ & $\mathrm{Fe}_{2} \mathrm{O}_{3}$ & $\mathrm{~K}_{2} \mathrm{O}$ & $\mathrm{MgO}$ & $\mathrm{Na}_{2} \mathrm{O}$ & $\mathrm{SO}_{3}$ & $\mathrm{Others}$ \\
\hline Slag & 32.83 & 17.19 & 36.69 & 0.38 & 0.37 & 8.20 & 0.65 & 1.94 & 1.75 \\
Pottery sand & 62.12 & 16.32 & 3.26 & 7.84 & 1.25 & 2.04 & 1.97 & - & 5.2 \\
\hline
\end{tabular}

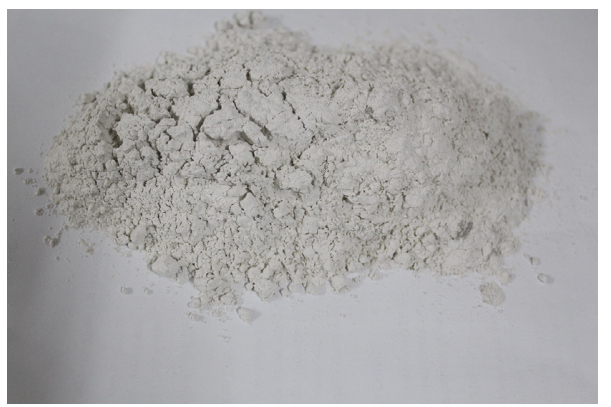

(a)

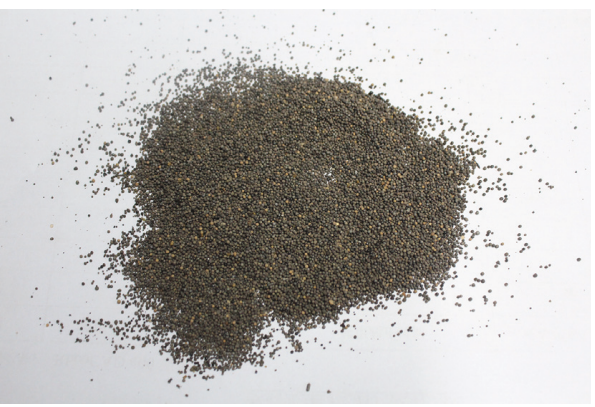

(b)

Figure 1: The cementitious material and fine aggregate. (a) Blast furnace slag. (b) Pottery sand.

properties. Many researchers [8-11] have investigated the role of recycled by-products as fine aggregates in AAS processes, including the use of granulated blast furnace slag, limestone aggregate, ladle slag, and waste glass. For example, Elibol and Sengul [12] investigated the use of natural sand and ferrochrome slag as a fine aggregate for the preparation of AAS mortars at $80^{\circ} \mathrm{C}$ for $28 \mathrm{~d}$, which gave AAS mortars with highest compressive strengths of 51.3 and $43.5 \mathrm{MPa}$, respectively. However, this process is economically unfeasible for industrial processes due to the high temperatures and extended times required during their curing phase. Alternatively, Aydin and Baradan [3] reported that AAS mortars containing crushed limestone sand exhibited high compressive strengths of $22.6 \mathrm{MPa}$ after $2 \mathrm{~d}$ and $99.0 \mathrm{MPa}$ after 90 d. Similarly, Zuda et al. [13] employed recycled electrical porcelain as a fine aggregate in an attempt to improve the high-temperature performance of AAS mortars, which gave flexural and compressive strengths of only 3.3 $\mathrm{MPa}$ and $22.6 \mathrm{MPa}$ at $25^{\circ} \mathrm{C}$, respectively. Huiskes et al. [14] have also described that an ultra-lightweight concrete manufactured from recycled glass aggregate demonstrates good mechanical performance and durability. However, no studies describing the use of readily available pottery sand (easily prepared from fly ash and bauxite) as a fine aggregate for the preparation of AAS mortars had been described. Consequently, we now report our investigation into the use of pottery sand as an aggregate material for the preparation of AAS mortar materials and demonstrate that they exhibit excellent setting, shrinkage, and hardness properties that make these mortars a potential useful building material for applications in the construction industry.

\section{Materials and Experimental Methods}

2.1. Materials. Blast furnace slag was obtained from the Tangshan steel plant in China, and the slag was classified as S95 according to GB/T 18046-2008, with a specific surface area of $424 \mathrm{~m}^{2} / \mathrm{kg}$. Pottery sand was prepared from fly ash and bauxite calcining with the high temperature of $1200-$ $1600^{\circ} \mathrm{C}$ and used as a fine aggregate with a particle size $\leq 1 \mathrm{~mm}$, a specific gravity of 1.8 , and a bulk density of $1.2 \mathrm{~g} / \mathrm{cm}^{3}$. The chemical composition of the slag and pottery sand is shown in Table 1. Images of the blast furnace slag and pottery sand are shown in Figure 1. The alkaline activator used for the AAS mortar was prepared using water glass and sodium hydroxide. The water glass used in this study was supplied by the Julide Chemical Co., Langfang, China, which contained 10.3\%, $32.1 \%$, and $57.6 \%$ of $\mathrm{Na}_{2} \mathrm{O}, \mathrm{SiO}_{2}$, and $\mathrm{H}_{2} \mathrm{O}$, respectively. $\mathrm{NaOH}$ pellets with a purity of $96 \%$ were supplied by Dalu Chemical Reagent Factory, Tianjin, China.

2.2. Mortar Preparation. Three different silicate moduli (1.2, 1.4 , and 1.6) and $\mathrm{Na}_{2} \mathrm{O}$ contents $(6 \%, 8 \%$, and $10 \%)$ were used to prepare the alkali activator. The $\mathrm{Na}_{2} \mathrm{O}$ contents in this study refer to $6 \%, 8 \%$, and $10 \% \mathrm{Na}_{2} \mathrm{O}$ with respect to the weight of slag. The water to slag ratio of the AAS mortar was 0.35 by mass, using slag to aggregate ratios of $1 / 1,1 / 1.25,1 / 1.5,1 / 1.75$, and $1 / 2$ by weight. Table 2 shows the mixing proportions used for preparing AAS mortars. AAS mortars were prepared by mixing the slag and pottery sand together for $5 \mathrm{~min}$, before the alkaline activator was added and the resultant slurry stirred for $1 \mathrm{~min}$ at a slow rate of $200 \pm 5 \mathrm{rpm}$, followed by stirring for $1 \mathrm{~min}$ at a faster rate of $400 \pm 10 \mathrm{rpm}$.

2.3. Methods. Fresh mortar, containing different mixtures of slag, silicate moduli, and $\mathrm{Na}_{2} \mathrm{O}$, were cast into cubic $(70.7 \mathrm{~mm} \times 70.7 \mathrm{~mm} \times 70.7 \mathrm{~mm})$ and prismatic $(25 \mathrm{~mm} \times$ $25 \mathrm{~mm} \times 280 \mathrm{~mm}$ ) moulds that were then subjected to compressive strength and drying shrinkage tests. Three duplicate samples were analyzed for each mixing proportion, with samples being stored in sealed containers covered with plastic foils to avoid water loss for $24 \mathrm{~h}$ at $20^{\circ} \mathrm{C}$. The samples used for compressive strength tests were demoulded and cured in the standard room $\left(20 \pm 22^{\circ} \mathrm{C}\right.$ and $\left.\mathrm{RH}>95 \%\right)$ and tested using an electrohydraulic machine at 1, 3, 7, 14, 
TABLE 2: The mixing proportions used in this study.

\begin{tabular}{|c|c|c|c|c|c|}
\hline Number of mix & Nomenclature $^{1,2,3,4}$ & Silicate modulus & $\mathrm{Na}_{2} \mathrm{O}$ content $(\%)$ & Slag to aggregate ratio & Water to slag ratio \\
\hline 1 & $\mathrm{M} 1.2 \mathrm{~N} 6 \mathrm{M}$ & 1.2 & 6 & $1 / 1.75$ & 0.35 \\
\hline 2 & M1.2N8M (SA1/1.75M) & 1.2 & 8 & $1 / 1.75$ & 0.35 \\
\hline 3 & $\mathrm{M} 1.2 \mathrm{~N} 10 \mathrm{M}$ & 1.2 & 10 & $1 / 1.75$ & 0.35 \\
\hline 4 & M1.4N6M & 1.4 & 6 & $1 / 1.75$ & 0.35 \\
\hline 5 & M1.4N8M & 1.4 & 8 & $1 / 1.75$ & 0.35 \\
\hline 6 & $\mathrm{M} 1.4 \mathrm{~N} 10 \mathrm{M}$ & 1.4 & 10 & $1 / 1.75$ & 0.35 \\
\hline 7 & M1.6N6M & 1.6 & 6 & $1 / 1.75$ & 0.35 \\
\hline 8 & M1.6N8M & 1.6 & 8 & $1 / 1.75$ & 0.35 \\
\hline 9 & M1.6N10M & 1.6 & 10 & $1 / 1.75$ & 0.35 \\
\hline 10 & $\mathrm{SA} 1 / 1 \mathrm{M}$ & 1.2 & 8 & $1 / 1$ & 0.35 \\
\hline 11 & $\mathrm{SA} 1 / 1.25 \mathrm{M}$ & 1.2 & 8 & $1 / 1.25$ & 0.35 \\
\hline 12 & $\mathrm{SA} 1 / 1.5 \mathrm{M}$ & 1.2 & 8 & $1 / 1.5$ & 0.35 \\
\hline 13 & $\mathrm{SA} 1 / 2 \mathrm{M}$ & 1.2 & 8 & $1 / 2$ & 0.35 \\
\hline
\end{tabular}

The first $\mathrm{M}=$ silicate modulus; $\mathrm{N}=\mathrm{Na}_{2} \mathrm{O}$ content; the last $\mathrm{M}=$ mortar; $\mathrm{SA}=$ slag to aggregate ratio.

and 28 days, respectively. The samples used for drying shrinkage/mass loss tests were stored in an isothermal chamber $\left(20 \pm 2^{\circ} \mathrm{C}\right.$ and $\left.\mathrm{RH}=(50 \pm 5) \%\right)$, with drying shrinkage levels determined using a micrometer over 28 days. Mass loss throughout the curing process was monitored using an electronic balance in accordance with JGJ/T 70-2009. The cross-sectional area of the stainless-steel needle of the measuring instrument used to determine mortar setting times was $30 \mathrm{~mm}^{2}$. Setting times were specified as the time taken from addition of the activator to the raw starting materials to the point where penetration resistance of the mortar reached $15 \mathrm{~N}$. Fluidity tests were performed using a jump table according to GB/T 2419-2005. Fresh mixtures were poured into truncated conical moulds that were then lifted into a vertical position, with the instrument then run through 25 cycles. The fluidity of each mortar was determined by measuring the average diameters of each sample along two perpendicular directions, with consistency measurements determined according to JGJ/T 70-2009. The average values of two tests were determined, with consistency and error limits between repeat samples found to be $<10 \mathrm{~mm}$. The morphologies of the microstructures of samples were determined using SEM-EDS using a ZEISS MERLIN Compact FE-SEM, Germany. The pore structures and porosities of each specimen were determined using Autopore IV 9500, Micromeritics Instrument Ltd., America.

\section{Results}

The aim of this study was to identify an optimal process for incorporating pottery sand into AAS mortars that would display good fluidity, consistency, compressive strength, and drying shrinkage properties, with the microstructures of promising mortars then being explored using SEM-EDS and MIP analysis.

\subsection{Effect of Slag to Aggregate Ratios on Composition of} Mortars. We initially investigated the effect of slag to aggregate ratios on the setting time, fluidity, and consistency of alkali-activated slag-derived mortars. Mortars were prepared using a water-to-slag ratio of 0.35 , using an alkali activator

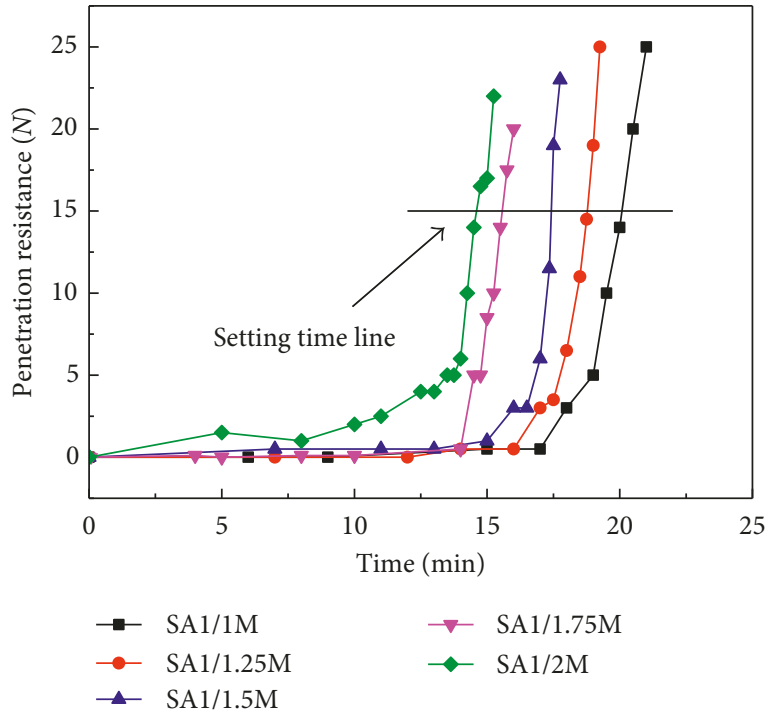

FIGURE 2: The effect of slag to aggregate ratios on the setting time of AAS mortars.

with a silicate modulus of 1.2 and a $\mathrm{Na}_{2} \mathrm{O}$ content of $8 \%$. The setting times observed for the AAS mortars ranged from 12 to $20 \mathrm{~min}$, with incorporation of larger amounts of pottery sand resulting in decreased mortar setting times (Figure 2). The fluidity and consistency values of the AAS mortars were also found to increase as the slag to aggregate ratio increased (Figure 3). For example, when the slag to aggregate ratio was increased from $1 / 2$ to $1 / 1$, the fluidity and consistency values of the mortar increased from 4.8 to $51.0 \%$ and 6.4 to $50.0 \%$, respectively. These values suggest that the use of relatively high slag to aggregate ratios can be used to improve the workability of these AAS mortars. These studies enabled us to determine that a slag-to-aggregate ratio of $1 / 1.75$ was the optimum value for preparing mortar for construction applications.

3.2. Setting Times of AAS Mortars. The setting times of AAS mortars increased as their $\mathrm{Na}_{2} \mathrm{O}$ content increased, with setting times of $12.6,15.5$, and $24.7 \mathrm{~min}$ for $6 \%, 8 \%$, and $10 \%$ $\mathrm{Na}_{2} \mathrm{O}$ content, respectively (Figure 4). Moreover, the setting 


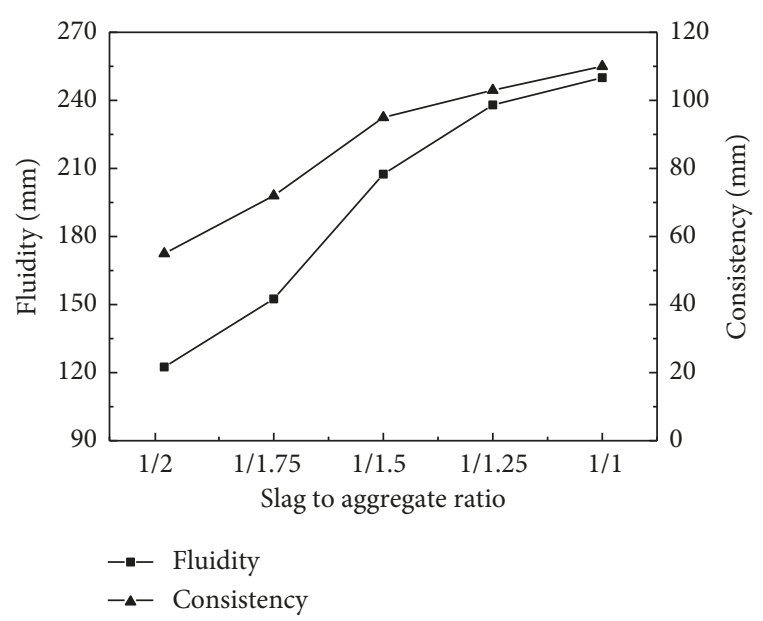

FIGURE 3: The effect of slag to aggregate ratios on the fluidity and consistency of AAS mortars.

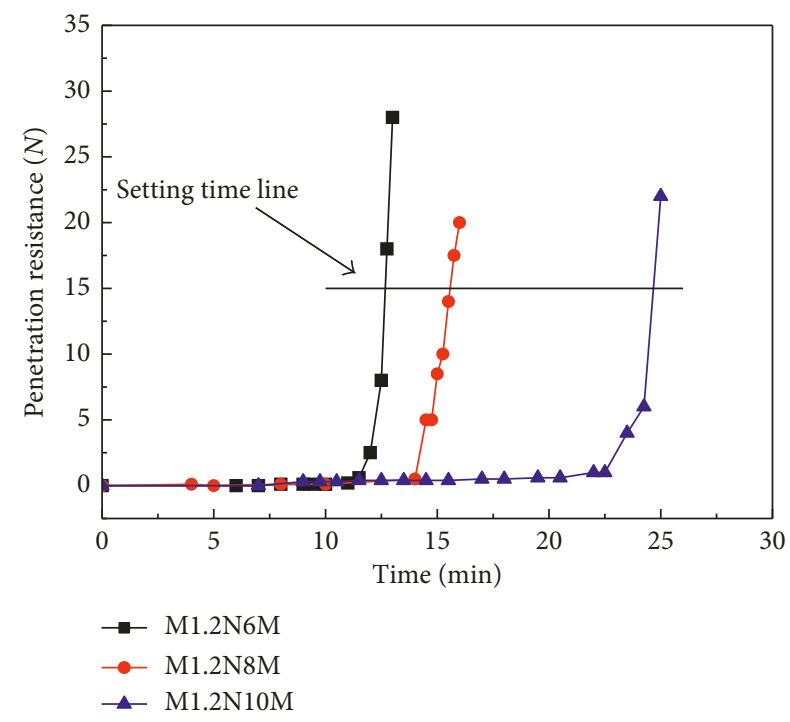

Figure 4: The effect of $\mathrm{Na}_{2} \mathrm{O}$ contents on the setting time of AAS mortars.

times of mortar were found to only increase slightly with increasing silicate modulus (Figure 5), indicating that this parameter was less influential than $\mathrm{Na}_{2} \mathrm{O}$ content. Gao et al. [15] indicated that the short setting time was due to the higher reactivity of slag in the high $\mathrm{pH}$ environment. In effect, more $\mathrm{Ca}, \mathrm{Si}$, and $\mathrm{Al}$ were dissolved by the slag which can effectively promote the formation of the hydration products; therefore, the condensation process was very fast.

3.3. Fluidity and Consistency of AAS Mortars. The fluidity and consistency of AAS mortars was found to increase as the silicate modulus increased (Figure 6). The slightly higher fluidity and consistency values were obtained using a $\mathrm{Na}_{2} \mathrm{O}$ content of $8 \%$, with silicate modulus playing an important role in determining the fluidity and consistency. Therefore, the fluidity of the mortar was found to increase

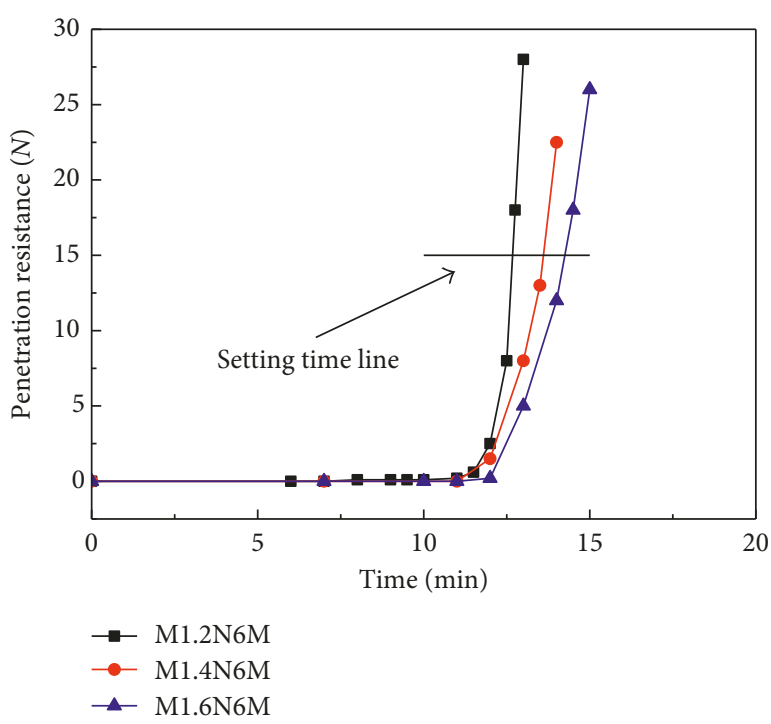

FIgURE 5: The effect of the silicate moduli on the setting time of AAS mortars.

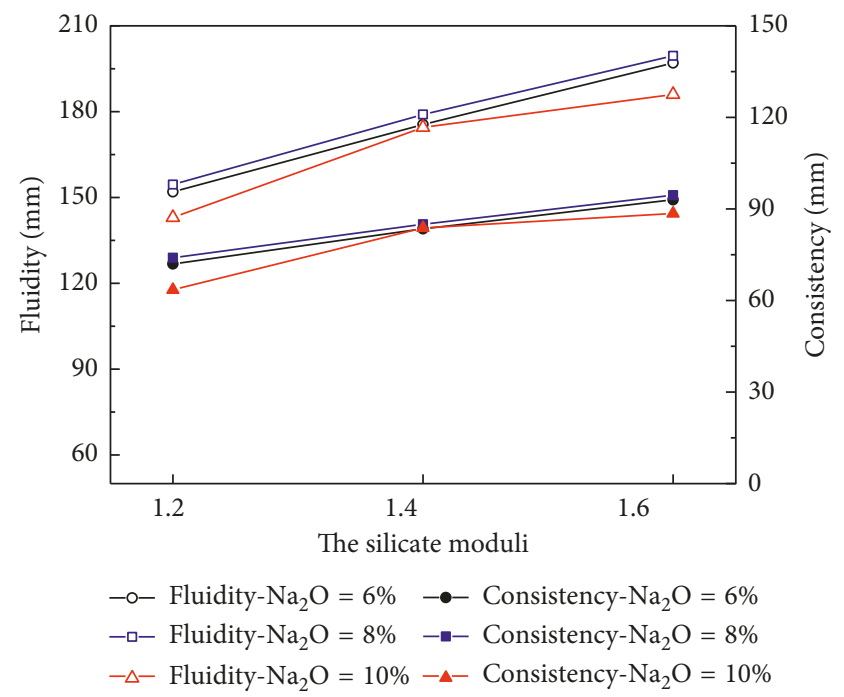

FIGURE 6: The effects of silicate moduli and $\mathrm{Na}_{2} \mathrm{O}$ contents on the fluidity and consistency of AAS mortars.

from 15.9 to $29.1 \%$ as the silicate modulus increased from 1.2 to 1.6 .

3.4. Compressive Strength. It was found that AAS mortars containing a slag-to-aggregate ratio of $1 / 1.75$ containing $8 \%$ $\mathrm{Na}_{2} \mathrm{O}$ exhibited maximal compressive strength (Figure 7), with mortars containing silicate modulus of 1.2, 1.4, and 1.6 exhibiting strengths of $123.2 \mathrm{MPa}, 113.2 \mathrm{MPa}$, and 118.2 MPa after $28 \mathrm{~d}$, respectively. Mortars containing an optimum silicate modulus of 1.2 afforded comparatively high compressive strength values of 81.4-93.2 MPa after only $1 \mathrm{~d}$ at room temperature. We propose that this high early compressive strength is mainly due to rapid formation of the C-S-H gel phase that exhibits a more condensed structure in the early stages of curing $[3,16]$. 


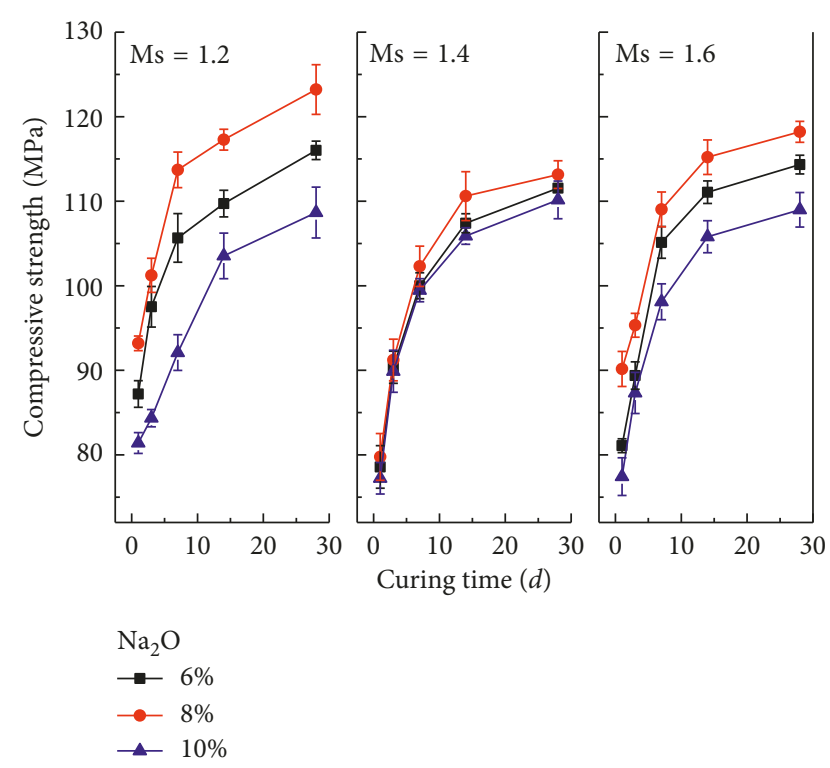

Figure 7: The effects of silicate moduli and $\mathrm{Na}_{2} \mathrm{O}$ contents on the compressive strength of AAS mortars.

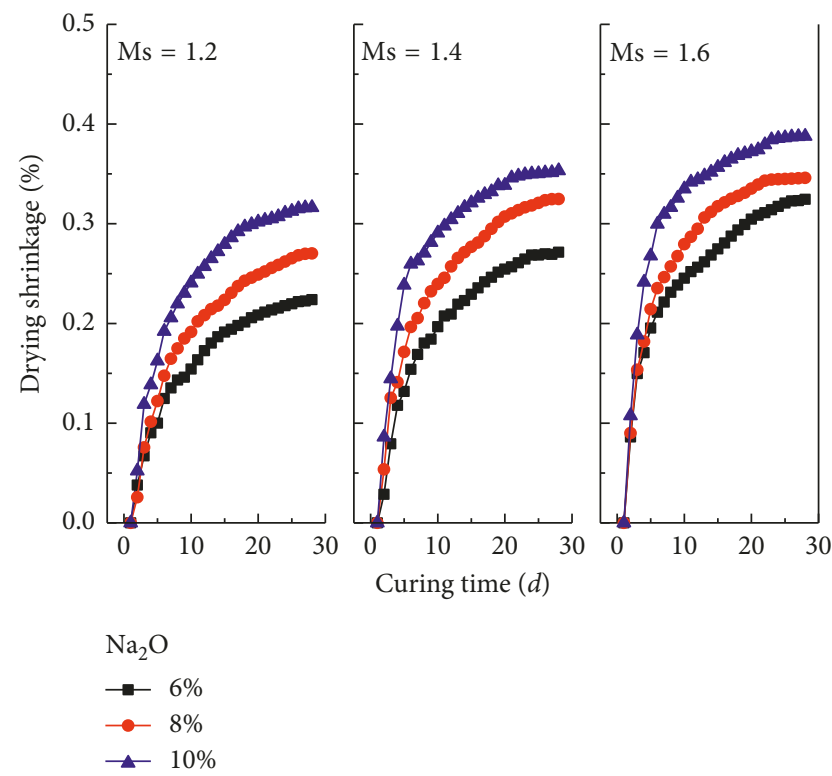

FIgURE 8: The effects of silicate moduli and $\mathrm{Na}_{2} \mathrm{O}$ contents on the drying shrinkage of AAS mortars.

3.5. Drying Shrinkage and Mass Loss of AAS Mortars during the Drying Process. Shrinkage of mortar in the drying process occurs because water molecules continuously evaporate from their surfaces, or through their pore structures [17]. The structure of the AAS mortars was observed over a period of $28 \mathrm{~d}$, with visual inspection revealing no obvious cracking of their external surfaces (Figure 8). It was found that drying shrinkage levels increased as both the $\mathrm{Na}_{2} \mathrm{O}$ content and the silicate moduli levels increased. For example, increasing the $\mathrm{Na}_{2} \mathrm{O}$ content from $6 \%$ to $10 \%$, using a silicate modulus of 1.6 resulted in an increase in drying shrinkage of the AAS mortars from $0.32 \%$ to $0.39 \%$ at

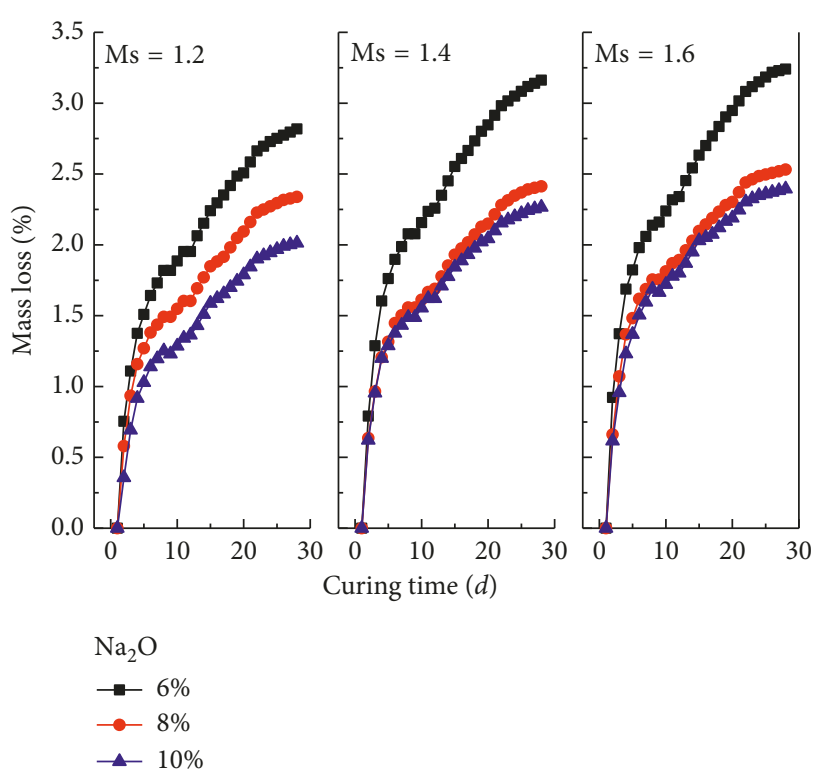

FIgure 9: The effect of silicate moduli and $\mathrm{Na}_{2} \mathrm{O}$ contents on the mass loss of AAS mortars.

$28 \mathrm{~d}$. They are also in agreement with work reported by Aydin and Baradan [3], Duran Atiş et al. [18], and others $[18,19]$ who also reported increased drying shrinkage levels when the amount of $\mathrm{Na}_{2} \mathrm{O}$ present in their mortars was increased. Mass losses from mortars were increased with decreasing $\mathrm{Na}_{2} \mathrm{O}$ content and increasing silicate modulus levels (Figure 9). These results are consistent with the results reported by Thomas et al. [20], who also found that the rate of water loss from mortars increases as their $\mathrm{Na}_{2} \mathrm{O}$ content decreased.

3.6. Characterization of Mortars Using Scanning Electron Microscopy with Energy Dispersive Spectrometry (SEM/EDS) and Mercury Intrusion Porosimetry (MIP). SEM/EDS images of AAS mortars containing silicate modulus of 1.2 and $\mathrm{Na}_{2} \mathrm{O}$ content of $8 \%$ at 1, 3, 7, and $28 \mathrm{~d}$ are shown in Figure 10. These images reveal significant changes in the interfacial transition zone of the hardened AAS mortars over time, with their microstructures becoming gradually denser as curing times increase. Additionally, mortars displaying more microcracks in their interfacial transition zones are visible after $1 \mathrm{~d}$, with fewer microcracks in their paste and interfacial transition zones being present after longer curing periods. These changes in structural morphology were mirrored by an increase in the compressive strength of AAS mortars over time (vide supra), which is consistent with strong interactions between the aggregate and paste playing an important role in providing compressive strength to the mortars [21]. It is better than the results by Aydin and Baradan who have also reported that microcracks were present in the interfacial aggregate-paste zones of their AAS mortars after $28 \mathrm{~d}$ [3].

The AAS mortars showed a clear demarcation at their aggregate and paste interface before $3 \mathrm{~d}$, with no distinction being visible after $7 \mathrm{~d}$. EDS analysis revealed that the 

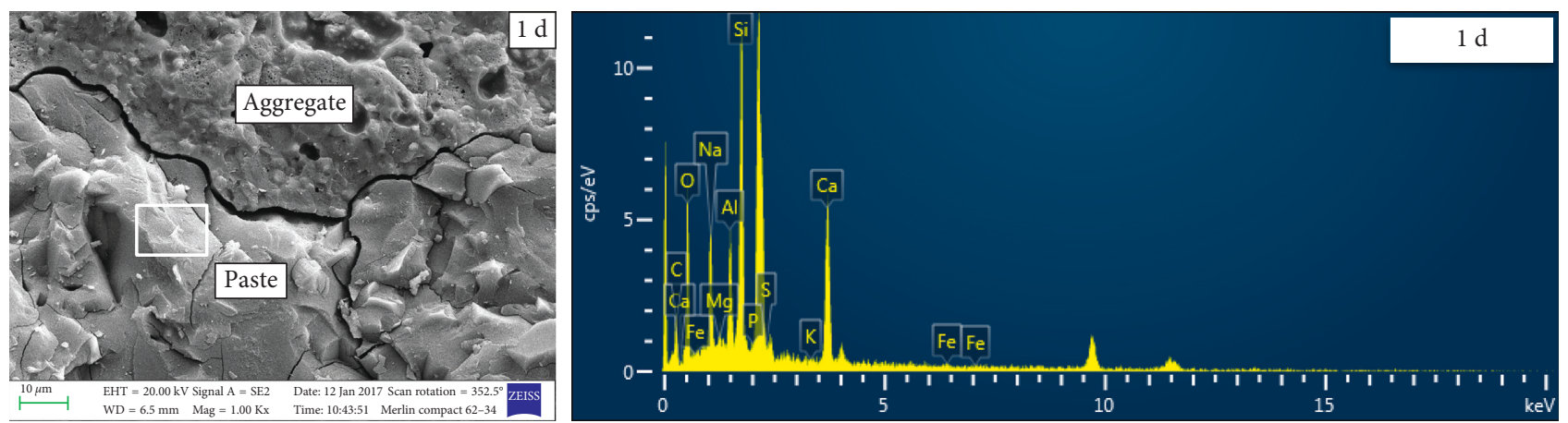

(a)
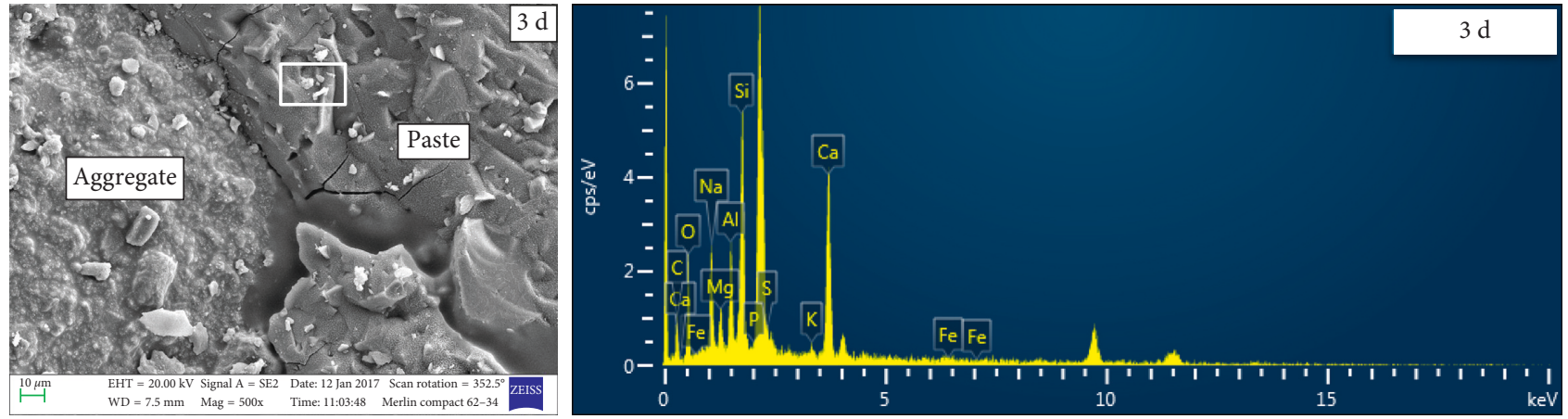

(b)
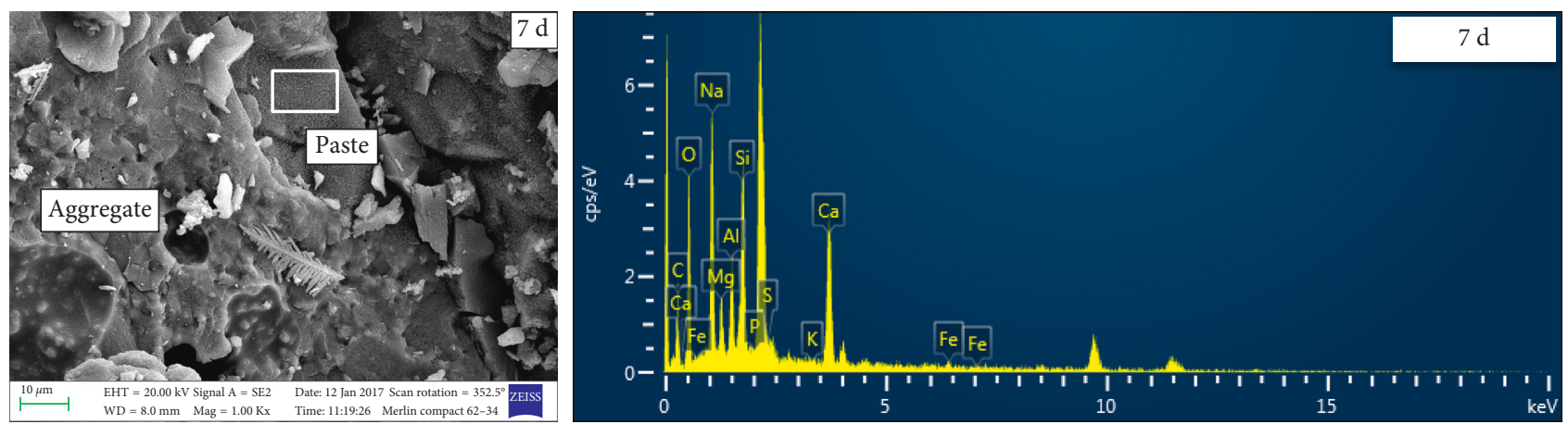

(c)
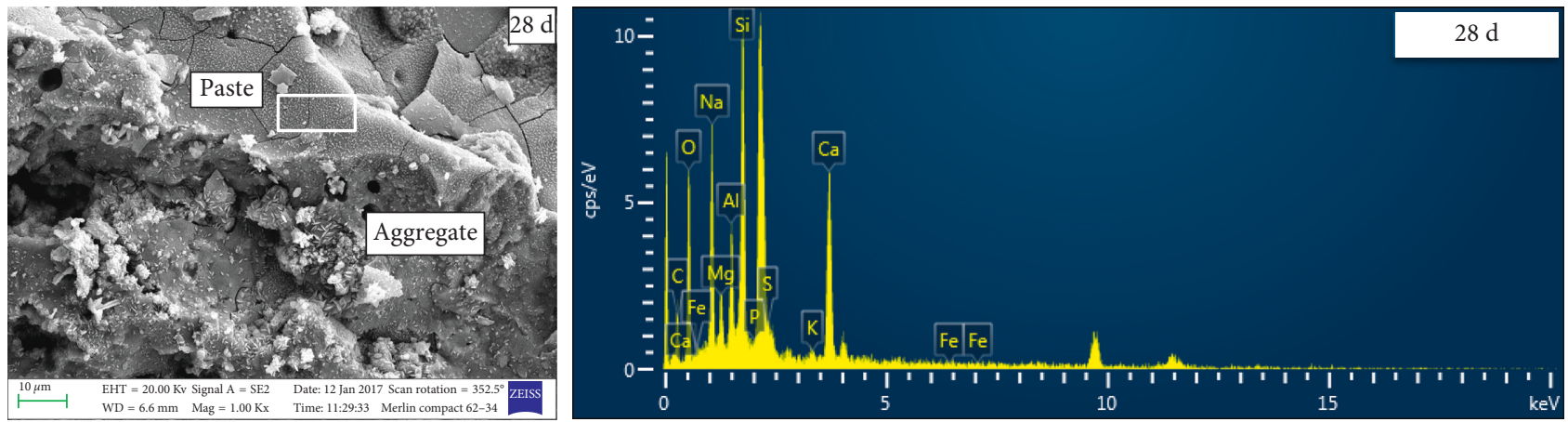

(d)

Figure 10: SEM/EDS of AAS mortars incorporated $8 \% \mathrm{Na}_{2} \mathrm{O}$ and $\mathrm{Ms}=1.2$ at different curing times: (a) $1 \mathrm{~d}$; (b) $3 \mathrm{~d}$; (c) $7 \mathrm{~d}$; (d) $28 \mathrm{~d}$.

main elements present in the AAS mortars were sodium, aluminum, silica, and calcium, with a $\mathrm{Ca} / \mathrm{Si}$ ratio of 0.60 , $0.97,0.89$, and 0.68 after $1,3,7$, and $28 \mathrm{~d}$, respectively. EDS analyses also revealed that the $\mathrm{C}-\mathrm{S}-\mathrm{H}$ gel phase contained elemental $\mathrm{Na}$, with the $\mathrm{Na} / \mathrm{Si}$ ratio found to be in a range from 0.63 to 1.90 , depending on the age of the sample. The $\mathrm{Ca} / \mathrm{Si}$ ratio of the AAS mortars was lower than those reported previously by Aydin and Baradan [3] for their 


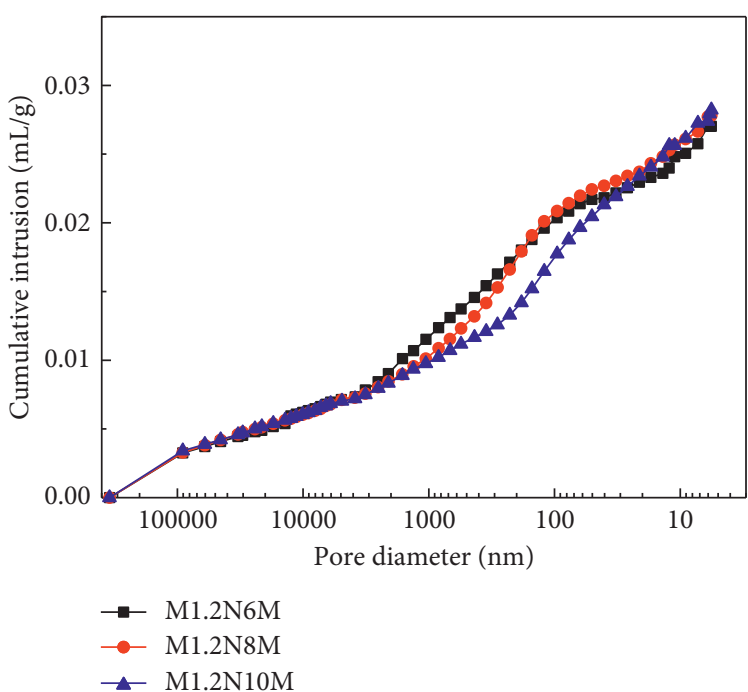

(a)

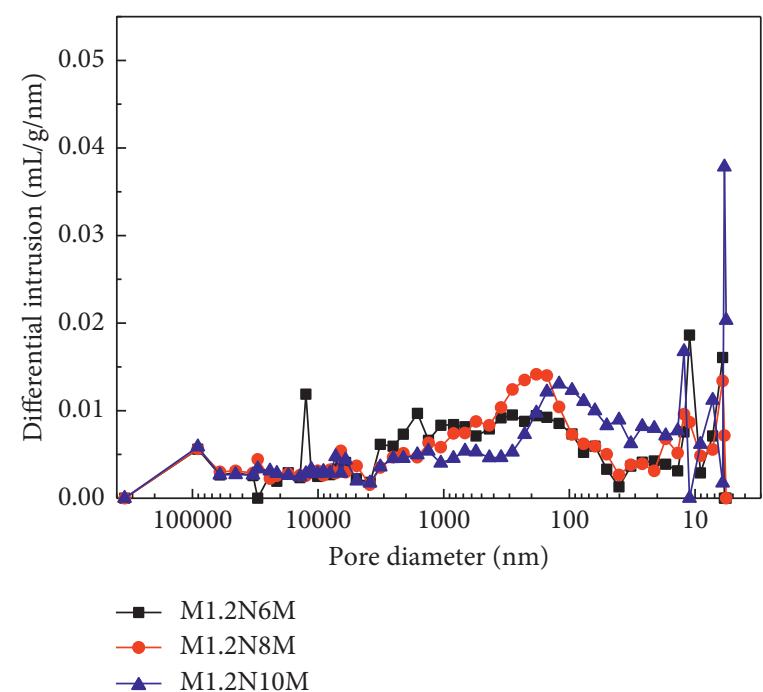

(b)

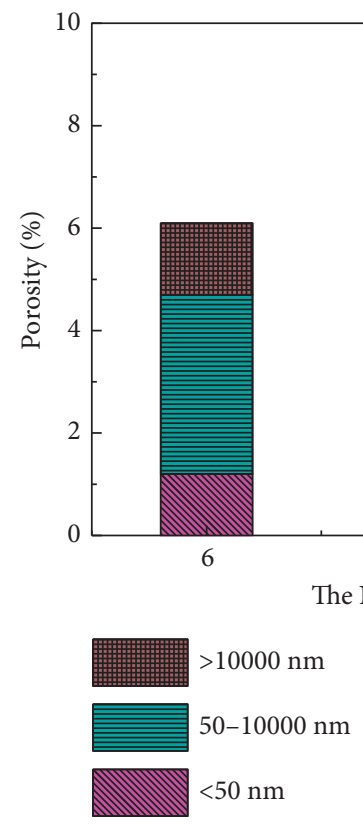

(c)

FIgURE 11: The pore size distribution of AAS mortars with different $\mathrm{Na}_{2} \mathrm{O}$ contents: (a) cumulative intrusion curves; (b) differential intrusion curves; (c) porosity.

mortars, whilst both the $\mathrm{Ca} / \mathrm{Si}$ and the $\mathrm{Na} / \mathrm{Si}$ ratio of the mortars were lower than those for mortars prepared by Gebregziabiher et al. [22]. They obtained that higher $\mathrm{Ca} / \mathrm{Si}$ and $\mathrm{Na} / \mathrm{Si}$ ratios represent the calcium and sodium-rich products on the surface of slag grains and the formation was denser.

Previous studies have reported that the size of the pore structure of the alkali-activated cement plays a critical role in determining the physical properties of AAS mortars [23, 24]. The effects of $\mathrm{N}_{2} \mathrm{O}$ content and silicate modulus on the pore structure of AAS mortars were studied (Figures 11 and 12). Analysis of the MIP results revealed the presence of peaks corresponding to pore size of $200 \mathrm{~nm}$ diameter, whose intensities were similar for all mortars tested. However, peaks corresponding to the presence of pores with a diameter between $500 \mathrm{~nm}$ and $3000 \mathrm{~nm}$ were significantly increased in mortars containing high silicate modulus levels. These MIP data also indicate that increasing $\mathrm{Na}_{2} \mathrm{O}$ content gave an increase in their mesoporous volume (pore size diameter $<50 \mathrm{~nm}$ ), with their overall pore volume remaining essentially constant (Figures 11(a) and 11(c)). Moreover, the total porosities of AAS mortars increased as the silicate modulus increased (Figure 12). Additionally, the mesopore volume increased with an increase in silicate modulus, which also can explain the drying shrinkage increase as the silicate modulus increased (mentioned above in Section 3.5). 


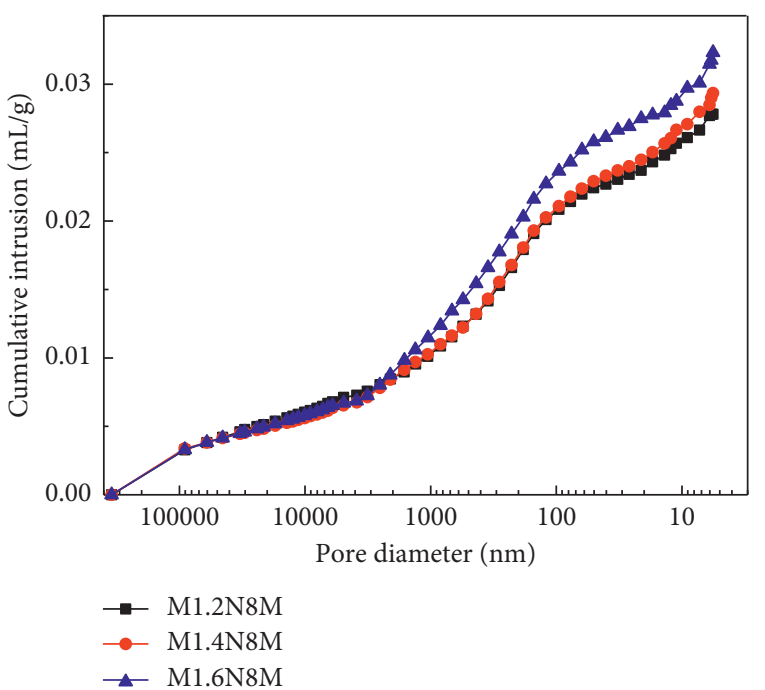

(a)

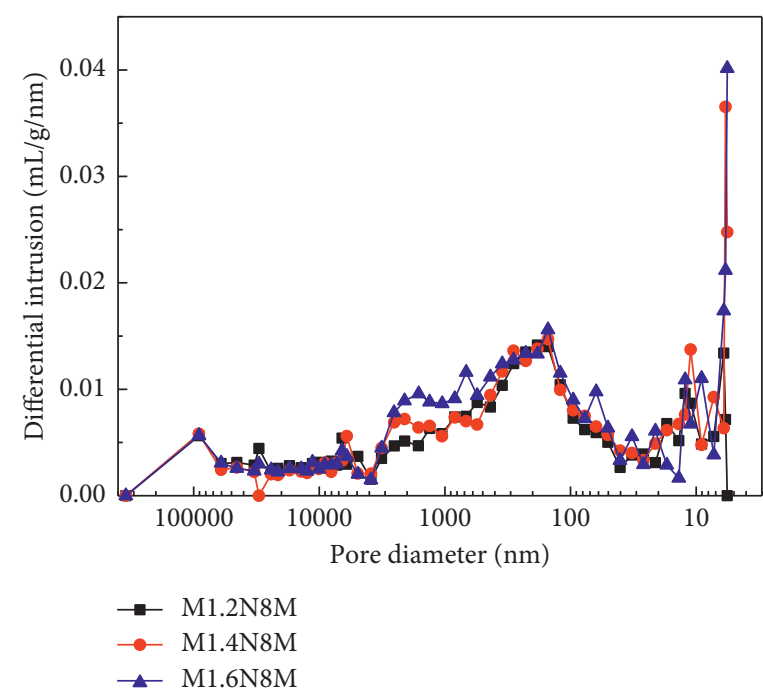

(b)

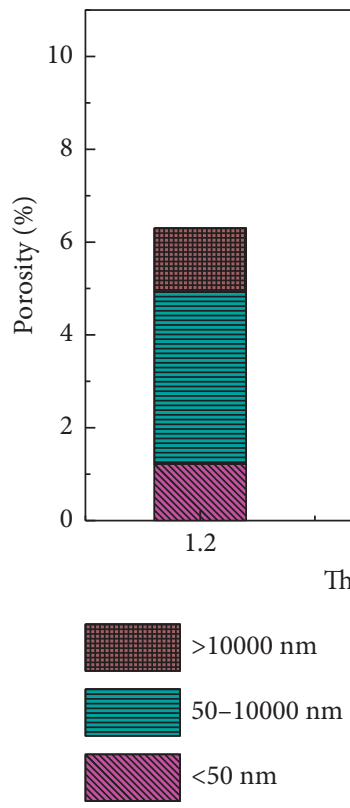

(c)

Figure 12: The pore size distribution of AAS mortars with different silicate moduli: (a) cumulative intrusion curves; (b) differential intrusion curves; (c) porosity.

\section{Discussion}

The composition of blast furnace slag has a significant effect on the physical properties of AAS mortars; therefore, it was necessary to optimize the alkaline activator conditions used for their preparation. A setting time of less than 30 minutes was targeted to match the specification required for quick repair cement [3], with setting times of 12-25 min observed for all pottery sand-containing AAS mortars tested in this study. JC 860-2008 specifications require that the consistency requirements for masonry mortar are between 50 and $80 \mathrm{~mm}$, with the AAS mortars that were prepared using a silicate modulus of 1.2 fully meeting these requirements.

There are differences in the fine aggregate types that have been incorporated into AAS mortars, and the aggregate type can thus affect the compressive strength. Optimization of the silicate modulus (1.2) and $\mathrm{Na}_{2} \mathrm{O}(8 \%)$ content gave AAS mortars with pottery sand that exhibited impressive maximal compressive strength levels of 93 and 123. $2 \mathrm{MPa}$ after $1 \mathrm{~d}$ and $28 \mathrm{~d}$, respectively. These compressive strength values compare favorably with those reported previously for mortars prepared from limestone and river sand aggregates, both of which gave lower values of $\leq 85 \mathrm{MPa}$ at $28 \mathrm{~d}[3,25]$.

The relatively high drying shrinkage levels observed for the mortars were also impressive, which is likely to be due to the fine capillary nature of their mesoporous microstructures [26]. There was the strong relationship between drying shrinkage and mesopore volume of the AAS mortars. The higher volumes of mesopores can lead to the larger drying 
shrinkage magnitudes due to the higher contracting stress derived from the finer capillary pores [26].

The interfacial transition zone between the aggregate and paste plays a key role in the development of compressive strength in the mortars [27]. However, the SEM images of the AAS mortars with pottery sand exhibited that the pottery sand was found to participate in the alkali reaction as an increasing of curing time, the cause of which is currently under investigation.

\section{Conclusions}

This study has shown that the setting time and fluidity/ consistency of AAS mortar derived from pottery sand increase as the slag to aggregate ratio increases, with an optimal ratio of $1 / 1.75$ being the best proportion for producing materials for construction applications. AAS mortars generally exhibited good setting properties (12-25 min), with their setting rates dependent on the proportion of $\mathrm{Na}_{2} \mathrm{O}$ present and their fluidity and consistency dependent on their silicate modulus content. Mortars containing $8 \% \mathrm{Na}_{2} \mathrm{O}$ exhibited good workability properties, with excellent compressive strength values being obtained after both 1 and $28 \mathrm{~d}$. Higher drying shrinkage levels were found for AAS mortars containing higher $\mathrm{Na}_{2} \mathrm{O}$ content and silicate modulus, with overall levels of mortar shrinkage dependent on the microporosity of their structure. The interfacial transition zone of these AAS mortars exhibited stronger bonding between gel products and the aggregate as curing times increased, with more microcracks present at the interfacial transition zone in the initial phase of curing than were present after more lengthy curing periods. In conclusion, these performance levels suggest that pottery sand-derived AAS mortars may be potentially useful as self-repairing materials for engineering or construction applications.

\section{Data Availability}

The data used to support the findings of this study are available from the corresponding author upon request.

\section{Conflicts of Interest}

The authors declare that there are no conflicts of interest regarding the publication of this paper.

\section{Acknowledgments}

This study was sponsored by the National Natural Science Foundation of China (Grant no. 51478142).

\section{References}

[1] S. Murgier, H. Zanni, and D. Gouvenot, "Blast furnace slag cement: a ${ }^{29} \mathrm{Si}$ and ${ }^{27} \mathrm{Al}$ NMR study," Comptes Rendus Chimie, vol. 7, no. 3-4, pp. 389-394, 2004.

[2] F. Puertas, S. Martínez-Ramírez, S. Alonso, and T. Vázquez, "Alkali-activated fly ash/slag cements: Strength behaviour and hydration products," Cement and Concrete Research, vol. 30, no. 10, pp. 1625-1632, 2000.
[3] S. Aydin and B. Baradan, "Effect of activator type and content on properties of alkali-activated slag mortars," Composites Part B: Engineering, vol. 57, pp. 166-172, 2014.

[4] R. San Nicolas, S. A. Bernal, R. M. de Gutierrez, J. S. J. van Deventer, and J. L. Provis, "Distinctive microstructural features of aged sodium silicate-activated slag concretes," Cement and Concrete Research, vol. 65, pp. 41-51, 2014.

[5] S. A. Bernal, J. L. Provis, R. J. Myers, R. San Nicolas, and J. S. J. van Deventer, "Role of carbonates in the chemical evolution of sodium carbonate-activated slag binders," Materials and Structures, vol. 48, no. 3, pp. 517-529, 2015.

[6] P. H. R. Borges, N. Banthia, H. A. Alcamand, W. L. Vasconcelos, and E. H. M. Nunes, "Performance of blended metakaolin/blastfurnace slag alkali-activated mortars," Cement and Concrete Composites, vol. 71, pp. 42-52, 2016.

[7] P. Nath and P. K. Sarker, "Effect of GGBFS on setting, workability and early strength properties of fly ash geopolymer concrete cured in ambient condition," Construction and Building Materials, vol. 66, pp. 163-171, 2014.

[8] A. M. Rashad, D. M. Sadek, and H. A. Hassan, "An investigation on blast-furnace stag as fine aggregate in alkaliactivated slag mortars subjected to elevated temperatures," Journal of Cleaner Production, vol. 112, pp. 1086-1096, 2016.

[9] A. R. Sakulich, E. Anderson, C. Schauer, and M. W. Barsoum, "Mechanical and microstructural characterization of an alkali-activated slag/limestone fine aggregate concrete," Construction and Building Materials, vol. 23, no. 8, pp. 2951-2957, 2009.

[10] E. Kamseu, M. Cannio, E. A. Obonyo et al., "Metakaolinbased inorganic polymer composite: Effects of fine aggregate composition and structure on porosity evolution, microstructure and mechanical properties," Cement and Concrete Composites, vol. 53, pp. 258-269, 2014.

[11] T. C. Ling and C. S. Poon, "Use of recycled CRT funnel glass as fine aggregate in dry-mixed concrete paving blocks," Journal of Cleaner Production, vol. 68, pp. 209-215, 2014.

[12] C. Elibol and O. Sengul, "Effects of activator properties and ferrochrome slag aggregates on the properties of alkaliactivated blast furnace slag mortars," Arabian Journal for Science and Engineering, vol. 41, no. 4, pp. 1561-1571, 2016.

[13] L. Zuda, J. Drchalova, P. Rovnanik, P. Bayer, Z. Kersner, and R. Cerny, "Alkali-activated aluminosilicate composite with heat-resistant lightweight aggregates exposed to high temperatures: mechanical and water transport properties," $\mathrm{Ce}$ ment and Concrete Composites, vol. 32, no. 2, pp. 157-163, 2010.

[14] D. M. A. Huiskes, A. Keulen, Q. L. Yu, and H. J. H. Brouwers, "Design and performance evaluation of ultra-lightweight geopolymer concrete," Materials and Design, vol. 89, pp. 516-526, 2016.

[15] X. Gao, Q. L. Yu, and H. J. H. Brouwers, "Properties of alkali activated slag-fly ash blends with limestone addition," Cement and Concrete Composites, vol. 59, pp. 119-128, 2015.

[16] F. Puertas and M. Torres-Carrasco, "Use of glass waste as an activator in the preparation of alkali-activated slag. Mechanical strength and paste characterisation," Cement and Concrete Research, vol. 57, pp. 95-104, 2014.

[17] Y. Ma and G. Ye, "The shrinkage of alkali activated fly ash," Cement and Concrete Research, vol. 68, pp. 75-82, 2015.

[18] C. Duran Atiş, C. Bilim, Ö. Çelik, and O. Karahan, "Influence of activator on the strength and drying shrinkage of alkaliactivated slag mortar," Construction and Building Materials, vol. 23, no. 1, pp. 548-555, 2009. 
[19] A. A. Melo Neto, M. A. Cincotto, and W. Repette, "Drying and autogenous shrinkage of pastes and mortars with activated slag cement," Cement and Concrete Research, vol. 38, no. 4, pp. 565-574, 2008.

[20] R. J. Thomas, D. Lezama, and S. Peethamparan, "On drying shrinkage in alkali-activated concrete: Improving dimensional stability by aging or heat-curing," Cement and Concrete Research, vol. 91, pp. 13-23, 2017.

[21] Subaer, Influence of Aggregate on the Microstructure of Geopolymer, Ph.D. thesis, Curtin University of Technology, Perth, Australia, 2004.

[22] B. S. Gebregziabiher, R. Thomas, and S. Peethamparan, "Very early-age reaction kinetics and microstructural development in alkali-activated slag," Cement and Concrete Composites, vol. 55, pp. 91-102, 2015.

[23] F. Collins and J. G. Sanjayan, "Effect of pore size distribution on drying shrinking of alkali-activated slag concrete," Cement and Concrete Research, vol. 30, no. 9, pp. 1401-1406, 2000.

[24] C. J. Shi, "Strength, pore structure and permeability of alkaliactivated slag mortars," Cement and Concrete Research, vol. 26, no. 12, pp. 1789-1799, 1996.

[25] M. Chi, J. Chang, and R. Huang, "Strength and drying shrinkage of alkali-activated slag paste and mortar," Advances in Civil Engineering, vol. 2012, Article ID 579732, 7 pages, 2012.

[26] Y. M. Gu, Y. H. Fang, D. You, Y. F. Gong, and C. H. Zhu, "Properties and microstructure of alkali-activated slag cement cured at below- and about-normal temperature," Construction and Building Materials, vol. 79, pp. 1-8, 2015.

[27] S. Demie, M. F. Nuruddin, and N. Shafiq, "Effects of microstructure characteristics of interfacial transition zone on the compressive strength of self-compacting geopolymer concrete," Construction and Building Materials, vol. 41, pp. 91-98, 2013. 


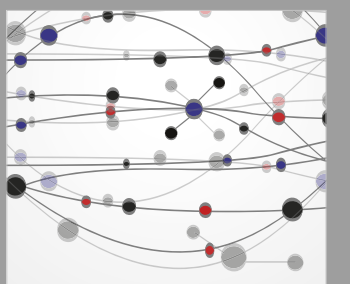

The Scientific World Journal
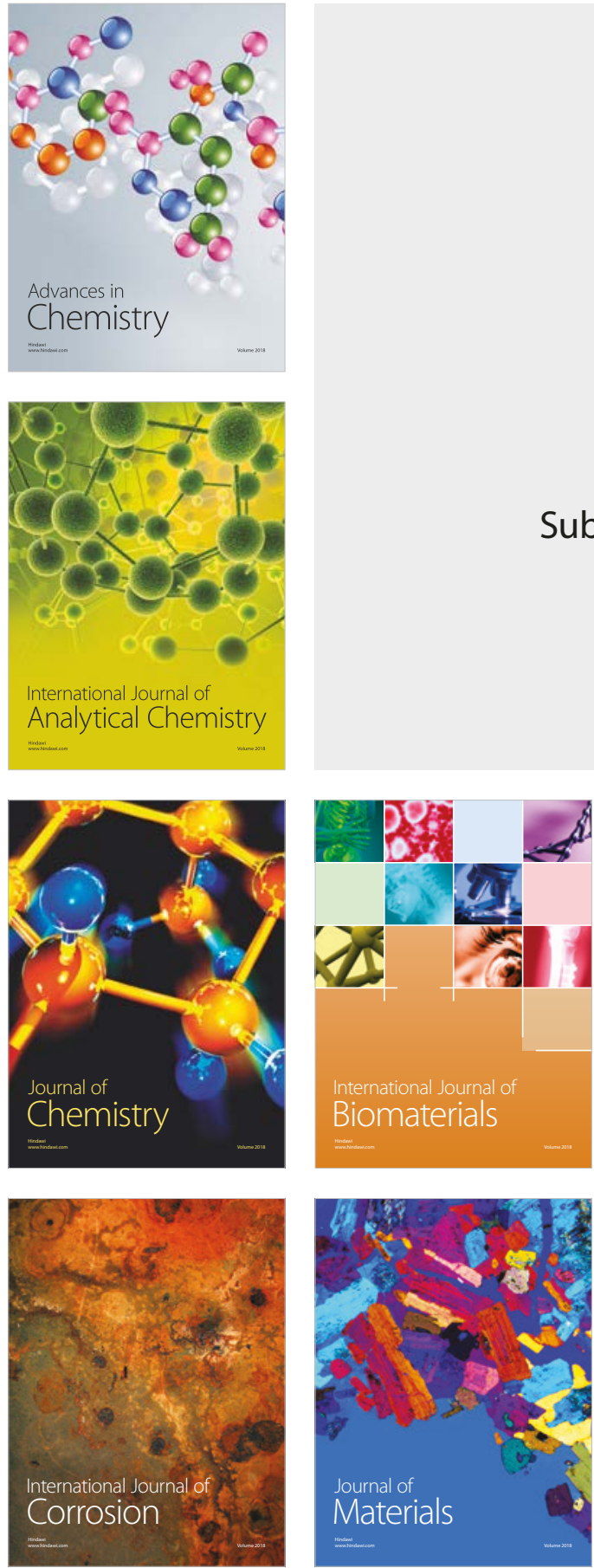

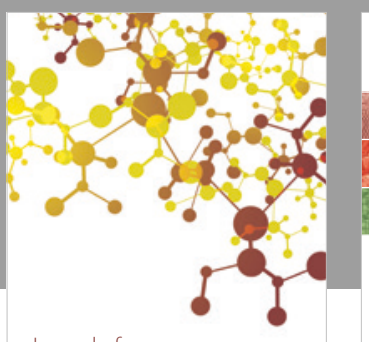

Journal of

Applied Chemistry
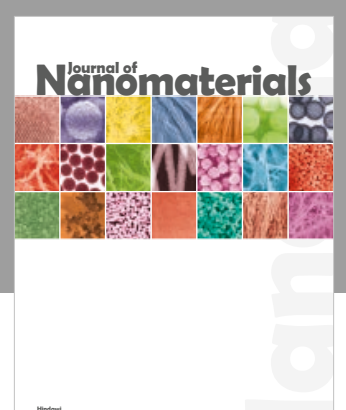

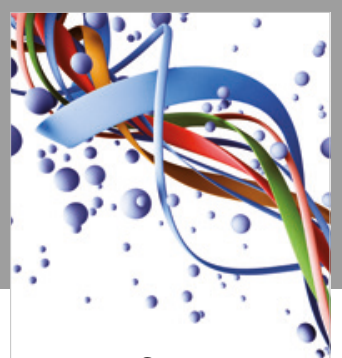

Scientifica

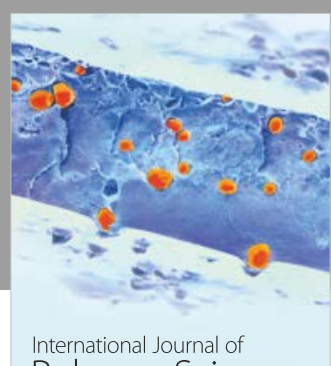

Polymer Science

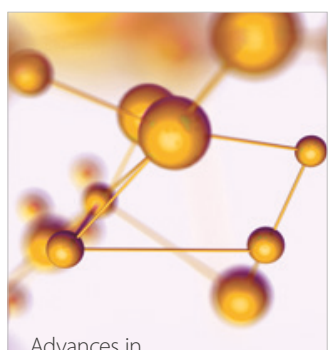

Physical Chemistry
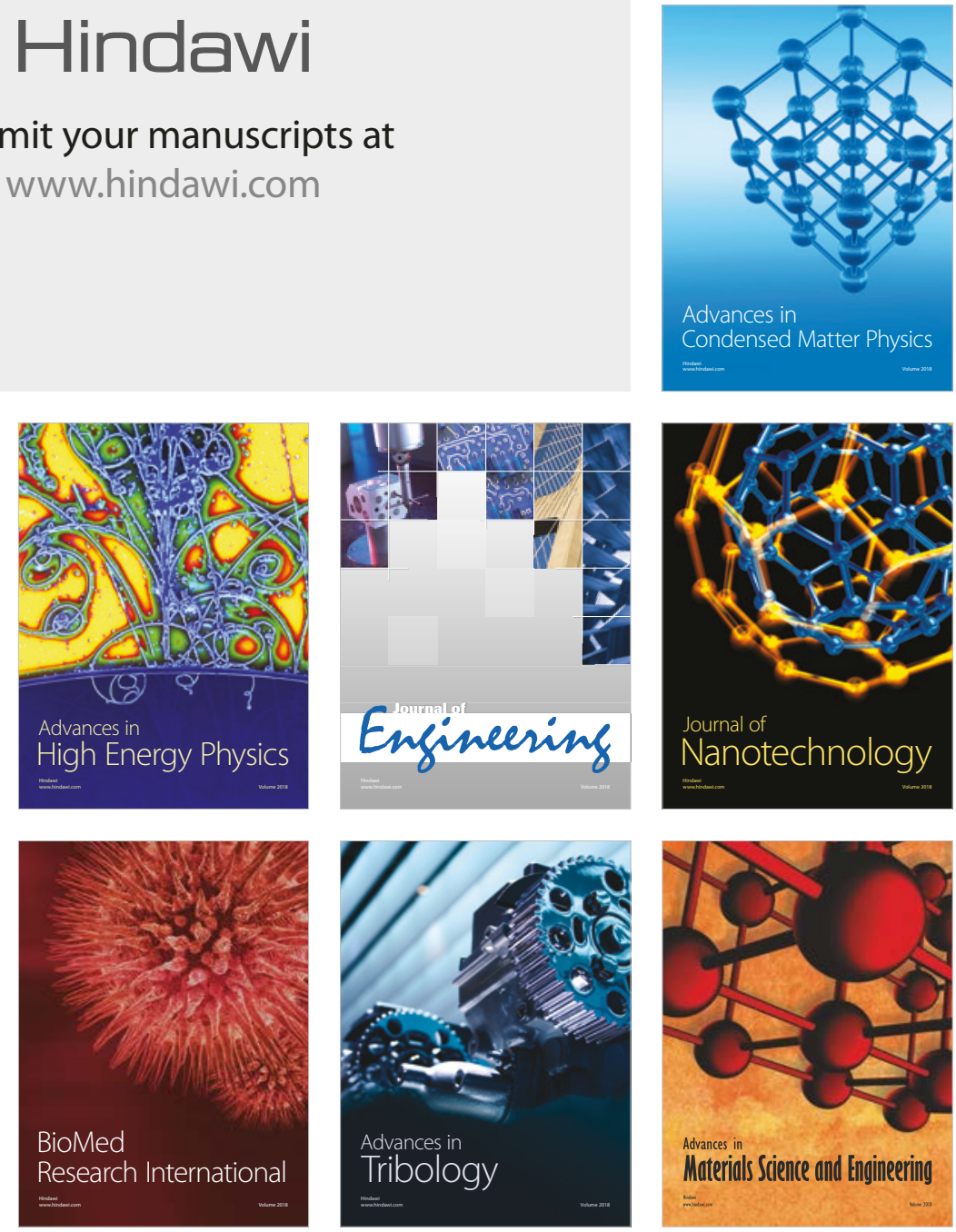